\section{Modeling the Relationship between Water Uptake by Cucumber and NaCl Accumulation in a Closed Hydroponic System}

\author{
Dimitrios Savvas, ${ }^{1}$ Gerasimos Meletiou, Spiridoula Margariti, and \\ Ioannis Tsirogiannis \\ Faculty of Agricultural Technology, TEI of Epirus, P.O. Box 110, 47100 Arta, \\ Greece
}

\section{Anastasios Kotsiras \\ Agricultural Institute of Filiatra, Agrokepion, 24300 Filiatra, Greece}

Additional index words. Cucumis sativus, nutrient modelling, salinity, salt stress, soilless culture

\begin{abstract}
In a completely closed hydroponic system, $\mathrm{Na}$ and $\mathrm{Cl}$ commonly accumulate in the root zone, at rates depending on the concentration of $\mathrm{NaCl}$ in the irrigation water (rate of $\mathrm{Na}$ and $\mathrm{Cl}$ inlet) and the $\mathrm{Na}$ to water and $\mathrm{Cl}$ to water ratios at which they are taken up by the plants (rates of $\mathrm{Na}$ and $\mathrm{Cl}$ outlet). However, while the concentration of $\mathrm{NaCl}$ in the irrigation water is commonly a constant, the $\mathrm{Na}$ to water and $\mathrm{Cl}$ to water uptake ratios are variables depending on the concentrations of $\mathrm{Na}$ and $\mathrm{Cl}$ in the root zone and, hence, on the rates of their accumulation. To quantify this feed-back relationship, a differential equation was established, relating the rate of $\mathrm{Na}($ or $\mathrm{Cl}$ ) accumulation to the rate of water uptake. This equation was solved according to the classical Runge-Kutta numerical method using data originating from a cucumber experiment, which was conducted in a fully automated, closed-loop hydroponic installation. Four different $\mathrm{NaCl}$ concentrations in the irrigation water, $0.8,5,10$ and $15 \mathrm{mM}$, were applied as experimental treatments. The theoretically calculated curves followed a convex pattern, with an initially rapid increase of the $\mathrm{Na}$ and $\mathrm{Cl}$ concentrations in the root zone and a gradual leveling out as the cumulative water consumption was rising. This was ascribed to the gradual approaching of the $\mathrm{Na}$ to water and Cl to water outlet ratios via plant uptake, which were increasing as $\mathrm{NaCl}$ was accumulating in the root zone, to the constant $\mathrm{NaCl}$ to water inlet ratio ( $\mathrm{NaCl}$ concentration in irrigation water). The model could predict the measured $\mathrm{Na}$ and $\mathrm{Cl}$ concentrations in the drainage water more accurately at 10 and $15 \mathrm{~mm} \mathrm{NaCl}$ than at 0.8 and $5 \mathrm{~mm} \mathrm{NaCl}$ in the irrigation water. Possible explanations for these differences are discussed. Plant growth and water uptake were restricted as salinity was increasing, following a reverse pattern to that of $\mathrm{Na}$ and $\mathrm{Cl}$ accumulation in the root zone. The leaf $\mathrm{K}, \mathrm{Mg}$ and $\mathrm{P}$ concentrations were markedly restricted by the increasing salinity, while that of $\mathrm{Ca}$ was less severely affected.
\end{abstract}

Closed hydroponic systems enabling recycling of the fertigation effluents in greenhouses are becoming increasingly important, due to limitations in irrigation water availability and environmental concerns (Savvas, 2002a; Van Os, 1999). However, accumulation of $\mathrm{NaCl}$ originating from the irrigation water may impose a partial discharge of drainage water (Carmassi et al., 2005; Raviv et al., 1998), thereby reducing the efficiency of closed systems to prevent groundwater contamination with nitrates and phosphates. The use of intelligent automation systems based on mass balance models in closed hydroponic systems could minimize the need to discharge drainage water, thereby reducing groundwater contamination (Le Bot et al., 1999). Since

Received for publication 31 Aug. 2004. Accepted for publication 2 Nov. 2004. This investigation was supported by the Greek Ministry of Education (YPEPTH) within the frame of the ARCHIMEDES research project, which was partly funded by EU.

${ }^{1}$ To whom reprint requests should be addressed; e-mailsavvas@teiep.gr. in terms of water use efficiency (Hopmans and Bristow, 2002). Also, this is in response to the dominant control of leaf-intercepted radiation on both assimilation and transpiration (Hsiao, 1993). Consequently, relationships between ion to water uptake ratios and the concentrations of these ions in the root zone may be established, by neglecting the impact of any other variable. The above consideration regarding the ion to water uptake ratios is valid also for $\mathrm{Na}$ and $\mathrm{Cl}$, since their active exclusion depends on the availability of energy derived from assimilation (Munns, 2002). Sonneveld et al. (1999) used the term "uptake concentrations" to describe the ion to water uptake ratios and showed that for $\mathrm{Na}$ and $\mathrm{Cl}$ these are exponential functions of their concentrations in the root zone.

In the present paper, we attempt to establish a relationship between $\mathrm{Na}$ or $\mathrm{Cl}$ concentration in the root zone and cumulative water uptake using a previously established equation between uptake concentrations and concentrations in the root zone (Savvas et al., 2005). The effects of progressively increasing salinity in closed hydroponic systems on plant growth and yield have been studied for few crop species (BarYosef et al., 1999, 2000; Raviv et al., 1998). However, there is no information on the effects of a progressive salinity build-up in the root zone due to recycling of the drainage solution on cucumber grown hydroponically. Therefore, the impact of $\mathrm{NaCl}$ accumulation in a closed system on cucumber growth, nutrient uptake, and water consumption, are also addressed in this study.

\section{Materials and Methods}

Cucumber(Cucumis sativus L. 'Camaron') seedlings grown in peat cubes $(4 \times 4 \times 4 \mathrm{~cm})$ were transferred at the stage of the third true leaf into channels connected to fully automated hydroponic installations, which enabled complete recycling of the drainage solution (Savvas, 2002b). The experiment was conducted in a glasshouse located in Arta (lat. $39^{\circ} 7^{\prime} \mathrm{N}$, long. 20 $\left.56^{\prime} \mathrm{E}\right)$, Greece. The channels were distributed over 12 independently operating hydroponic systems, which constituted the experimental units. Each experimental unit consisted of two channels, $5 \mathrm{~m}$ in length, accommodating 20 plants (10 plants/channel). Porous polyurethane slabs $(100 \times 20 \times 6 \mathrm{~cm})$ were used as substrate. The crop density was 1.6 plants per $\mathrm{m}^{2}$. The plants were pruned according to the umbrella training system (Klieber et al., 1993). Excessively high summer temperatures were controlled by passive ventilation and automatically operated shading screens. Trickle irrigation was automatically applied by means of a suitable computer program, at intervals depending on solar radiation intensity, which was monitored using a solar energy sensor. All channels were covered with polyethylene sheets and thus water evaporation was negligible. Furthermore, no drainage water was deliberately discharged and any losses due to technical failures were negligible.

Four different nutrient solution treatments were established in a randomized block design, with three blocks. In all treatments, the entire 
Table 1. Initial $\mathrm{Na}$ and $\mathrm{Cl}$ concentrations $(\mathrm{mM})$, and $\mathrm{EC}\left(\mathrm{dS} \cdot \mathrm{m}^{-1}\right)$ in drainage solution sampled from the 12 experimental units on the date of recycling initiation (day 0).

\begin{tabular}{|c|c|c|c|c|c|c|c|c|c|}
\hline \multirow{3}{*}{$\begin{array}{l}\mathrm{NaCl} \text { concn in } \\
\text { irrigation water } \\
(\mathrm{mM})\end{array}$} & \multicolumn{3}{|c|}{$\mathrm{Na}$} & \multicolumn{3}{|c|}{$\mathrm{Cl}$} & \multicolumn{3}{|c|}{ EC } \\
\hline & \multicolumn{3}{|c|}{ Replication } & \multicolumn{3}{|c|}{ Replication } & \multicolumn{3}{|c|}{ Replication } \\
\hline & 1 & 2 & 3 & 1 & 2 & 3 & 1 & 2 & 3 \\
\hline$\overline{0.8}$ & 1.83 & 1.68 & 1.77 & 1.69 & 1.55 & 1.46 & 2.32 & 2.28 & 2.28 \\
\hline 5.0 & 7.15 & 7.36 & 7.19 & 6.85 & 6.90 & 6.65 & 2.90 & 2.95 & 2.94 \\
\hline 10.0 & 13.56 & 13.17 & 13.79 & 12.82 & 13.41 & 13.89 & 3.65 & 3.61 & 3.71 \\
\hline 15.0 & 21.28 & 20.15 & 20.49 & 19.35 & 19.01 & 18.82 & 4.54 & 4.42 & 4.49 \\
\hline
\end{tabular}

quantity of drainage water after each application of nutrient solution (irrigation cycle) was captured and recycled in the next watering cycle, regardless of its volume. Nevertheless, the drainage fraction was maintained within the range $0.35-0.45$ by properly manipulating the cumulative sum of solar energy at which an irrigation events was triggered off. The supply of nutrients was in all treatments identical and could be maintained roughly constant throughout the experiment by means of a previously developed model based on frequent determination of the nutrient concentrations in the drainage water (Savvas, $2002 b$ ). The concentration of $\mathrm{NaCl}$ in the fresh irrigation water was $0.8 \mathrm{mM}$. To obtain irrigation water containing 5,10 , and $15 \mathrm{~mm}$ $\mathrm{NaCl}$ in the salinity treatments, the required quantity of $\mathrm{NaCl}$ was automatically computed and injected whenever fresh nutrient solution was prepared, as described in a previous paper (Savvas et al., 2004).

The cucumber seedlings were planted on June 13. Immediately after planting, the seedlings were supplied with nutrient solutions of different $\mathrm{NaCl}$ concentrations, depending on the irrigation water used in each treatment. Recycling of the drainage solution was initiated on 18 June (day 0 ) and the experiment was terminated on 16 Oct. The volume of fresh nutrient solution supplied to the crop at each irrigation event, as well as that of the drainage water collected thereafter and recycled, were automatically recorded in a Microsoft Access database and used to calculate the cumulative uptake of water by the crop. The effect of the increasing $\mathrm{NaCl}$ salinity on plant growth was investigated by sampling the vegetative shoot of two plants per experimental unit $0,9,23$, 57,91 , and $125 \mathrm{~d}$ after planting and measuring its dry weight. Furthermore, samples of drainage solution were collected $0,8,22,38,56$, 78,100 , and $120 \mathrm{~d}$ after treatment (recycling) initiation and analysed to determine the $\mathrm{Na}$ and $\mathrm{Cl}$ concentrations. The volume of drainage water was similar in all sampling dates. To study the effects of the increasing salinity on the nutrient status of the plant, samples of young leaves (5th leaf from the apex) were collected 31, 64, 96 and $120 \mathrm{~d}$ after treatment initiation, and used to determine the concentrations of $\mathrm{K}, \mathrm{Ca}, \mathrm{Mg}$ and $\mathrm{P}$.

The concentration of $\mathrm{Na}$ in the drainage solution was measured by atomic absorption spectrophotometry (GBC 932A/A), while that of chloride was determined by titration with $\mathrm{AgNO}_{3}$ in the presence of $\mathrm{K}_{2} \mathrm{CrO}_{4}$ (Eaton et al., 1995). All leaf samples were dried at 80 ${ }^{\circ} \mathrm{C}$ to constant weight, ground, and used to extract $\mathrm{K}, \mathrm{Ca}, \mathrm{Mg}$, and $\mathrm{P}$ by means of $1 \mathrm{M}$ $\mathrm{HCl}$ after dry ashing at $550{ }^{\circ} \mathrm{C}$ for 5 hours.
The concentrations of $\mathrm{K}, \mathrm{Ca}$, and $\mathrm{Mg}$ in the obtained extract were determined by atomic absorption spectrophotometry. Phosphorus was measured in the same extract by the vanadomolybdophosphoric acid colorimetric method at $460 \mathrm{~nm}$ (Eaton et al., 1995) using a Hitachi U-2001 spectrophotometer.

The data regarding water consumption, yield, and tissue nutrient concentrations were subjected to single factor analyses of variance and plotted in graphs using the PlotIT3.2 ${ }^{\circledR}$ work package. The significance of differences between the treatment means in Figures 1, 4 and 5 is indicated by vertical bars depicting \pm standard errors.

\section{Model outline}

Assuming that water losses via evaporation or discharge of drainage water were negligible, the total volume of water introduced into the closed system, henceforth denoted by $V_{w}$, was equal to that removed via transpiration. The nutrient solution remaining into the closed system, henceforth denoted by the subscript $s$, comprises the solution retained by the substrate and that collected as drainage water. Its volume $\left(V_{s}\right)$ fluctuated only slightly with a mean value of $5.25 \mathrm{~L} /$ plant throughout the cropping period, depending on the drainage fraction, which ranged between 0.35 to 0.45 , and can, thus, be considered constant. We assume that the concentrations of $\mathrm{Na}$ and $\mathrm{Cl}$ $(\mathrm{mM})$ in the nutrient solution remaining into the closed system, which are denoted by $C_{x s}$ $(\mathrm{x}=\mathrm{Na}, \mathrm{Cl})$, are approximately equal with those measured in the drainage solution. The only source of $\mathrm{Na}$ and $\mathrm{Cl}$ input into the closed system was the $\mathrm{NaCl}$ of the irrigation water, whose concentration (mM) is denoted by $C_{x w}$. This value was constant throughout the cropping period. Since the system was completely closed, the only outlet for $\mathrm{Na}$ and $\mathrm{Cl}$ was the absorption by the plant, at uptake concentrations $\left(\mathrm{mmol} \cdot \mathrm{L}^{-1}\right)$ denoted by $C_{x u}$. Any $\mathrm{NaCl}$ impurities originating from fertilizers, or solid $\mathrm{NaCl}$ depositions on emitters etc. due to evaporation of nutrient solution, are considered negligible. Under these conditions, any increase of $C_{x s}$ is proportional to the increase of $V_{w}$ and to the difference between the rates of $\mathrm{NaCl}$ inlet and $\mathrm{NaCl}$ outlet $\left(C_{x w}-C_{x u}\right)$, and inversely proportional to $\mathrm{V}_{\mathrm{s}}$. Mathematically, this relationship is written as follows:

$d C_{x s}=d V_{w}\left(C_{x w}-C_{x u}\right) / V_{s}$

Rearranging Eq. [1], one obtains the following differential equation:

$d C_{x s} / d V_{w}=\left(C_{x w}-C_{x u}\right) / V_{s}$

According to Sonneveld et al. (1999), $C_{x u}$ may be expressed as a function of $C_{x s}$ :

$C_{x u}=a C_{x s}{ }^{b}$ where $a$ and $b$ are constant values depending on the crop species. Eq. [3] may be used in a generalized form by introducing an additional constant c to model Na or Cluptake as a function of its concentration in the root zone:

$C_{x u}=a C_{x s}^{b}+c$

Replacing [4] in [2] one obtains:

$d C_{x s} / d V_{w}=\left(C_{x w}-a C_{x s}{ }^{b}-c\right) / V_{s}$

[5] (Savvas et al., 2005), we applied nonlinear regression analysis by using Eq. [4] as a model and we found that $a$ was 0.021 and $0.074, b$ was 1.652 and 1.302 , and $c$ was -0.014 and 0.191 , for $\mathrm{Na}$ and $\mathrm{Cl}$, respectively. Hence, Eq. [5] can be written as

$d C_{\text {Nas }} / d V_{w}=\left(C_{w}-0.021\left(C_{N a s}\right)^{1.652}+0.014\right) / 5.25$

for sodium, and

$d C_{C l s} / d V_{w}=\left(C_{w}-0.074\left(C_{C l s}\right)^{1.302}+0.191\right) / 5.25$

for chloride.

Eq. [5] is of the type:

$(d y / d x)=p y^{q}+r$ formula $y=g(x)$ (analytical solution) satisfying [8]. Numerical methods have to be used. We use the classical Runge-Kutta method of order four (Butcher, 1987). The independent variable $V_{w}$ (cumulative water uptake in liters per plant) ranged within the interval $[0,200]$ in our experimental treatments. Therefore, Eq. [3] is going to be approximated within the interval $[0,200]$. The values $C_{x s, 0}$ for $V_{w, 0}=0$ (Table 1$)$, which were measured in the drainage solution on the date of recycling initiation (day 0 ) are used as starting values. We define:

$F\left(C_{x s}\right)=\left(C_{w}-a C_{x s}^{b}-c\right) / V_{s}$

Hence, Eq. [5] becomes

$\left(d C_{x s} / d V_{w}\right)=F\left(C_{x s}\right)$

According solution of Eq. [10] consists of number pairs $\left(C_{x s, 0} V_{w, 0}\right),\left(C_{x s, 1} V_{w, 1}\right),\left(C_{x s, 2} V_{w, 2}\right),, \ldots$ etc., which can be computed as follows:

$V_{w, 0}=0, V_{w, 1}=h, V_{w, 2}=2 h, V_{w, 3}=3 h, \ldots$, where $h$ is the step, a small positive number (Butcher, 1987). We use the auxiliary variables $K_{1}, K_{2}$, $K_{3}, K_{4}$ and get $K_{1}=h F\left(C_{x s}, n\right), K_{2}=h F\left(C_{x s, n}+\right.$ $\left.\left(K_{1} / 2\right)\right), K_{3}=h F\left(C_{x s, n}+\left(K_{2} / 2\right)\right), K_{4}=h F\left(C_{x s, n}\right.$ $\left.+K_{3}\right)$, and finally $C_{x s,(n+1)}=C_{x s, n}+(1 / 6)\left(K_{1}^{x s, n}+\right.$ $2 K_{2}+2 K_{3}+K_{4}$ ) for $n=1,2,3 \ldots$

The size of the error of this method is $O\left(h^{5}\right)$. We choose $h=0.005$, which rendered a good approximation.

\section{Results and Discussion}

After continuous recycling of the drainage water for $120 \mathrm{~d}$, the cumulative uptake of water by cucumber was $194 \mathrm{~L} /$ plant, when the $\mathrm{NaCl}$ concentration in the irrigation water used to compensate for transpiration losses was 0.8 $\mathrm{mM}$. The use of irrigation water containing 5 , 10 or $15 \mathrm{~mm} \mathrm{NaCl}$, which resulted in much 


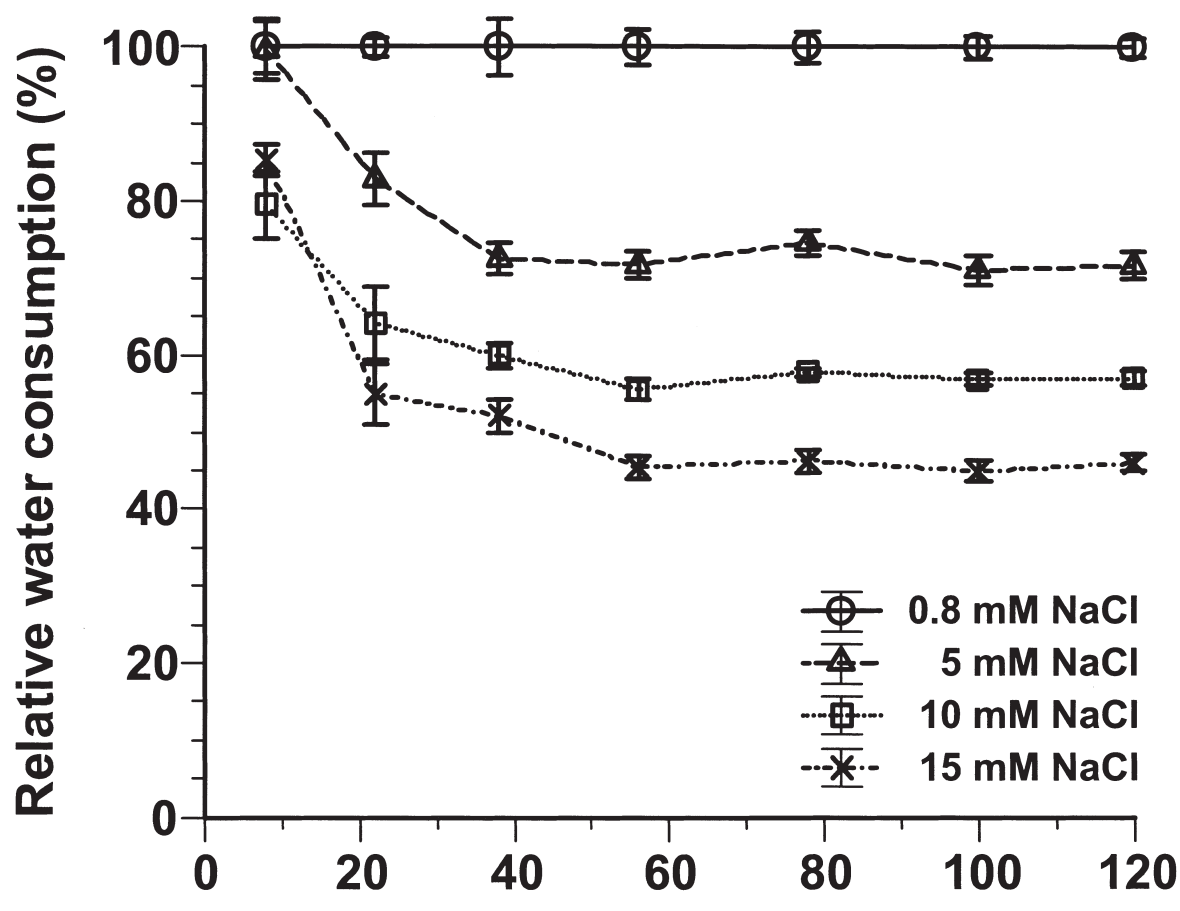

Fig. 1. Cumulative water consumption during $120 \mathrm{~d}$ of drainage solution recycling in a cucumber crop grown in a completely closed hydroponic system as influenced by the $\mathrm{NaCl}$ concentration in the irrigation water used to compensate for transpiration losses. Data are presented on a relative basis as a percentage of the treatment with the highest water consumption.

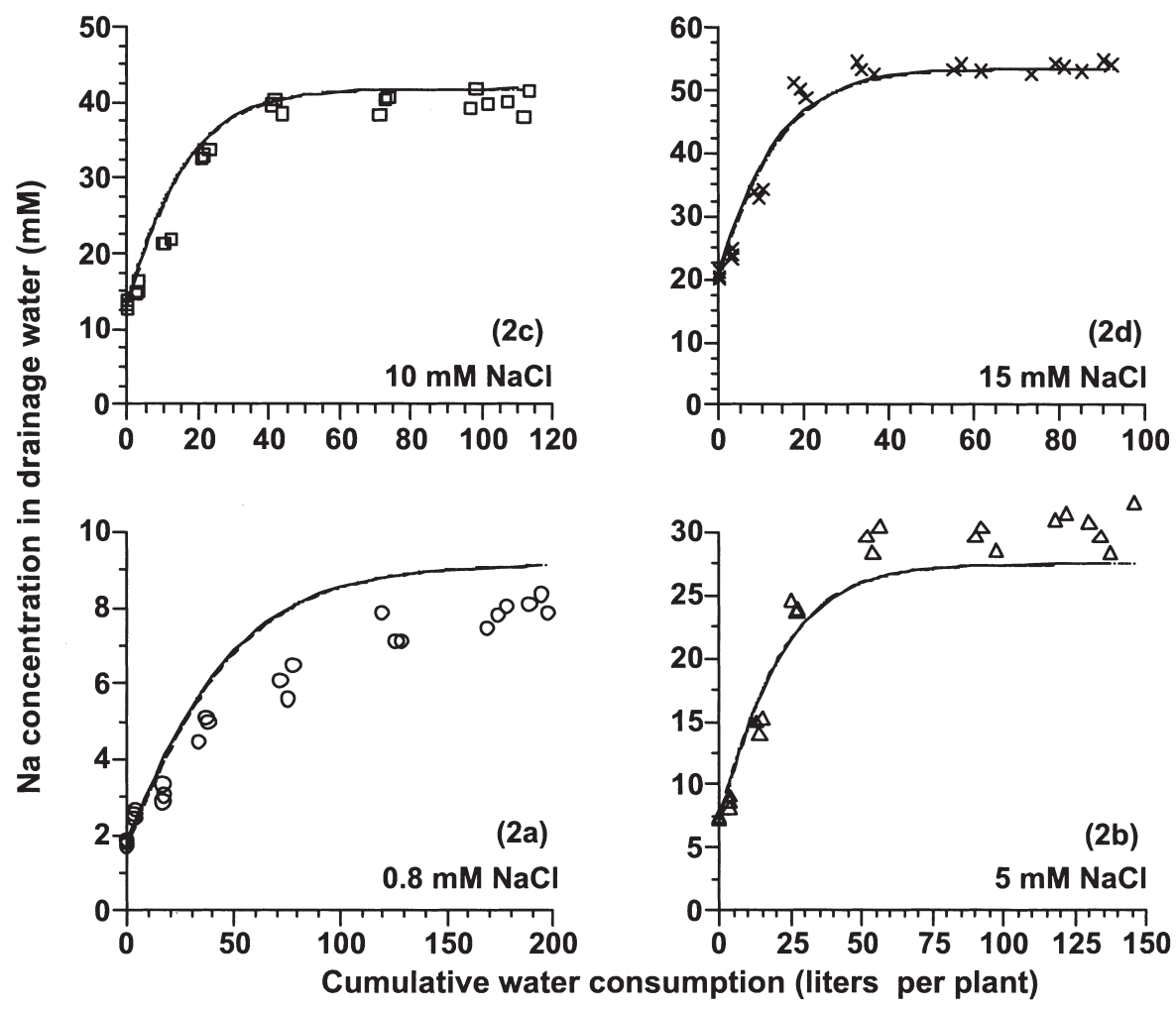

Fig. 2. Sodium concentrations in the drainage water as relationships of the cumulative water consumption during $120 \mathrm{~d}$ of drainage solution recycling. Data originate from cucumber crops grown in completely closed hydroponic systems with four different $\mathrm{NaCl}$ concentrations in the irrigation water used to compensate for transpiration losses. In each graph, lines indicate the values obtained by solving Eq. [6], while symbols depict measured values in three independent replications.

higher $\mathrm{NaCl}$ concentrations in the root zone (see below), restricted significantly the uptake of water to $71.7 \%, 57 \%$, and $46 \%$, respectively, of that consumed when the $\mathrm{NaCl}$ concentration transpiring leaf area (Greenway and Munns, 1980). Partial closure of stomatal aperture, which is a well known response of cucumber to salinity (Drew et al., 1990) may have additionally restricted the total water consumption.

Solving Eqs. [6] and [7] according to the Runge-Kutta method rendered the curves shown in Figs. $2(\mathrm{Na})$ and $3(\mathrm{Cl})$, respectively. These curves predict the courses of $\mathrm{Na}$ and $\mathrm{Cl}$ concentrations $\left(C_{r s}\right)$ in the root zone of cucumber grown in closed hydroponic systems as functions of the water consumption when the $\mathrm{NaCl}$ concentration in the irrigation water used to compensate for transpiration is $0.8,5,10$, or $15 \mathrm{~mm}\left(C_{x w}\right)$. The actual pairs of values for water consumption and the corresponding $\mathrm{Na}$ and $\mathrm{Cl}$ concentrations measured in the drainage water during the experiment, are depicted by symbols in Figs. 2 and 3, respectively.

Since all drainage solution was recycled, the volume of irrigation water introduced into the system was equal to that consumed by the plants. The $\mathrm{Na}$ to water and $\mathrm{Cl}$ to water outlet ratios, which were exclusively due to plant uptake, were enhanced as water consumption was increasing, because $\mathrm{NaCl}$ was accumulating in the root zone with time. However, the $\mathrm{NaCl}$ to water inlet ratio $(\mathrm{NaCl}$ concentration in irrigation water) was constant. Consequently, the differences between inlet and outlet in the $\mathrm{Na}$ to water and $\mathrm{Cl}$ to water ratios were decreasing as the cumulative water consumption was increasing and this resulted in a convex pattern of $\mathrm{Na}$ and $\mathrm{Cl}$ increase in the root zone. The obtained curves provided excellent prediction of the actual $\mathrm{Na}$ and $\mathrm{Cl}$ concentrations in the root zone at 10 and 15 $\mathrm{mM} \mathrm{NaCl}$ in the irrigation water used to compensate for transpiration losses (Figs. 2c and d, and $3 \mathrm{c}$ and $\mathrm{d}$, respectively). At $5 \mathrm{~mm} \mathrm{NaCl}$ in the irrigation water, the ultimate concentration of $\mathrm{Na}$ in the root environment, as predicted by the model, was slightly underestimated, but the divergence from the measured values was still satisfactorily short (Fig. 2b). However, at 0.8 $\mathrm{mM} \mathrm{NaCl}$ in the irrigation water, the predicted $\mathrm{Na}$ concentrations were rather overestimated (Fig. 2a). With respect to $\mathrm{Cl}$, the course of its accumulation could be only roughly predicted by Eq. [7] when the $\mathrm{NaCl}$ concentration in the irrigation water was 0.8 and $5 \mathrm{~mm}$ (Figs. 3a and $3 \mathrm{~b}$, respectively).

The data shown in Figs. 2 and 3 reveal that the model described by Eq. [5] may be used to relate the rate of salt accumulation in the root zone of cucumber grown in closed hydroponic systems to the cumulative water consumption. However, the ability of Eq. [5] to accurately predict the concentrations of $\mathrm{Na}$ and $\mathrm{Cl}$ in the root zone depends also on the determination of good estimates for $a, b, c$, as well as on a precise measurement of $\mathrm{V}_{\mathrm{s}}$. The parameters $a, b$, and $c$, which may vary considerably among different crop species, are determined by empirical means using nonlinear regression analysis (Savvas et al., 2005; Sonneveld et al., 1999). It is well known that the ability of the plants to minimize the net accumulation of sodium and/or chloride ions is a multigenic trait (Flowers, 2004) and hence each gene can be expressed at different external $\mathrm{NaCl}$ 

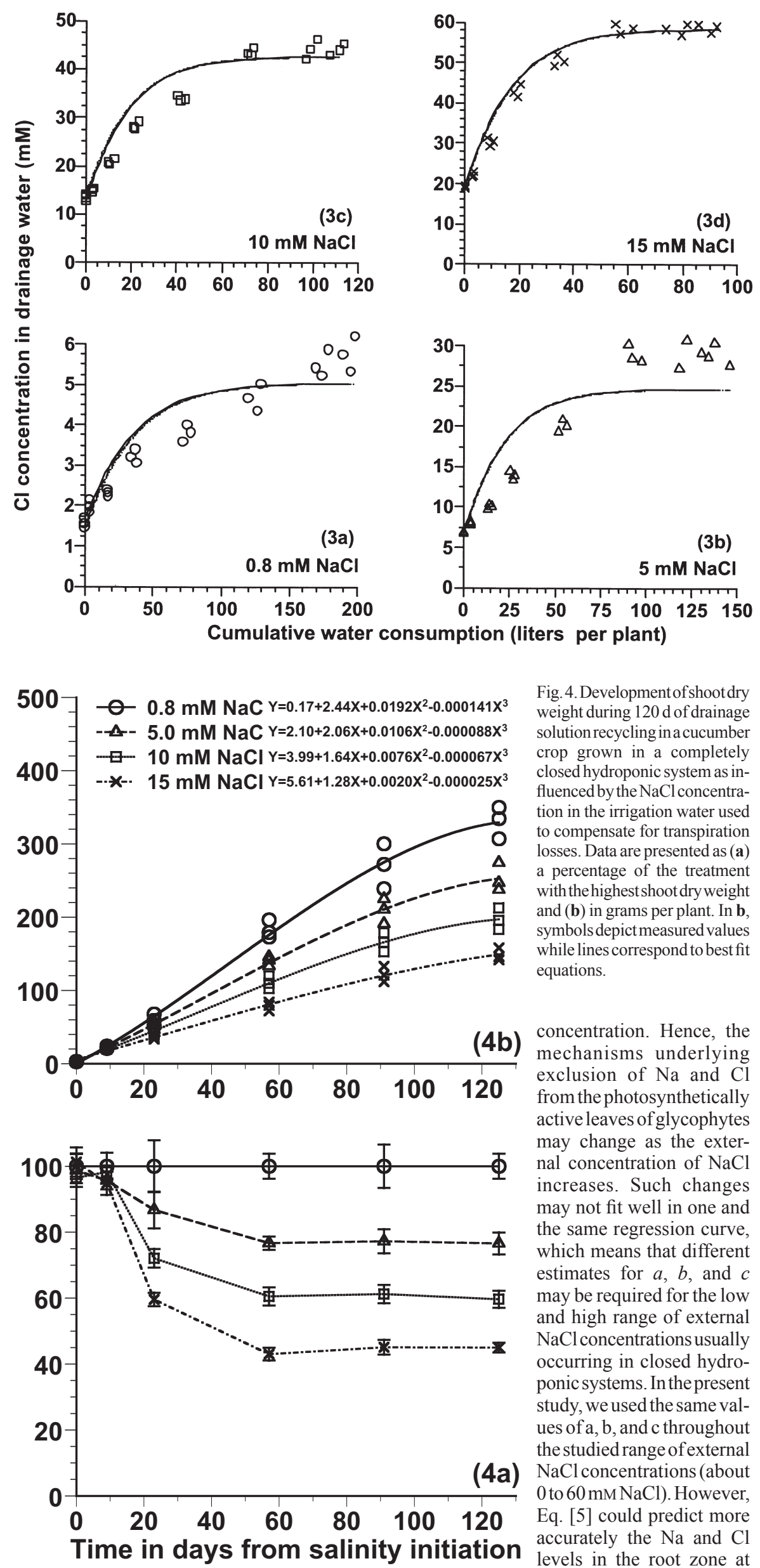

Fig. 4. Development of shootdry weight during $120 \mathrm{~d}$ of drainage solution recycling in a cucumber crop grown in a completely closed hydroponic system as influenced by the $\mathrm{NaCl}$ concentration in the irrigation water used to compensate for transpiration losses. Data are presented as (a) a percentage of the treatment with the highest shoot dry weight and (b) in grams per plant. In b symbols depict measured values while lines correspond to best fit equations.

concentration. Hence, the mechanisms underlying exclusion of $\mathrm{Na}$ and $\mathrm{Cl}$ from the photosynthetically active leaves of glycophytes may change as the external concentration of $\mathrm{NaCl}$ increases. Such changes may not fit well in one and the same regression curve, which means that different estimates for $a, b$, and $c$ may be required for the low and high range of external $\mathrm{NaCl}$ concentrations usually occurring in closed hydroponic systems. In the present study, we used the same values of $a, b$, and $c$ throughout the studied range of external $\mathrm{NaCl}$ concentrations (about 0 to $60 \mathrm{~mm} \mathrm{NaCl})$. However, Eq. [5] could predict more accurately the $\mathrm{Na}$ and $\mathrm{Cl}$ levels in the root zone at
Fig. 3. Chloride concentrations in the drainage water as relationships of the cumulative water consumption during $120 \mathrm{~d}$ of drainage solution recycling. Data originate from cucumber crops grown in completely closed hydroponic systems with four different $\mathrm{NaCl}$ concentrations in the irrigation water used to compensate for transpiration losses. In each graph, lines indicate the values obtained by solving Eq. [7], while symbols depict measured values in three independent replications.

10 and 15 than at 0.8 and $5 \mathrm{~mm} \mathrm{NaCl}$ in the irrigation water. Hence, it is reasonable to conclude that the values of $a, b$, and $c$ used in the present study fitted better at high than at low external $\mathrm{NaCl}$ concentrations.

Another aspect to consider with respect to the efficiency of the model described by Eq. [5] to predict the $\mathrm{Na}$ and $\mathrm{Cl}$ concentrations in the root environment is the validity of a, $\mathrm{b}$, and $\mathrm{c}$ under various climatic conditions. It has been stated that the coupling between ion uptake and transpiration rates may disappear at very high transpiration rates (Hopmans and Bristow, 2002), thereby imposing variable uptake concentrations at different dates, even if the concentrations of the corresponding ions in the external solution remain identical (Adams, 2002). Consequently, the high transpiration rates occurring during the summer in our experiment (approximately up to day 80 from treatment initiation) may have occasionally led to higher $\mathrm{Na}$ and $\mathrm{Cl}$ uptake concentrations than those corresponding to the values of a, b, and c used in the present study, which were based on data partly gained in autumn (Savvas et al., 2005). As a result, the concentrations of $\mathrm{Na}$ and $\mathrm{Cl}$ in the root zone, which were computed by setting the same values of $a, b$, and $c$ in Eq. [5] throughout the experiment, may appear overestimated during the summer period when compared with the measured values. This consideration is in agreement with the results shown in Fig. 3 but not with those in Fig. 2, which indicates that such seasonal effects may have influenced mainly the uptake of chloride.

Carmassi et al. (2004) proposed also a model relating the ionic concentration in the nutrient solution comprised in a closed hydroponic system with the ionic and the water uptake. However, these researchers supposed a linear relationship between uptake concentration and concentration of the respective ion in the root environment. With most plant species, exponential relationships between uptake concentrations of $\mathrm{Na}$ and $\mathrm{Cl}$ and their concentrations in the root environment seem to fit better to experimental data, especially in case of $\mathrm{Cl}$ (Baas et al., 1995; Sonneveld et al., 1999).

The progressive increase of $\mathrm{NaCl}$ concentration in our closed hydroponic systems due to the presence of 5,10 , and $15 \mathrm{mM} \mathrm{NaCl}$ in the irrigation water suppressed significantly the shoot dry weight of cucumber to $76.6 \%$, $59.6 \%$, and $45 \%$, respectively (Fig. $4 a$ ). In particular, the dry weight of the shoot (stem and leaves) at the end of the experiment was $350,247,183$, and $158 \mathrm{~g}$ per plant when the transpiration losses were compensated for by using irrigation water with $0.8,5,10$, and 15 

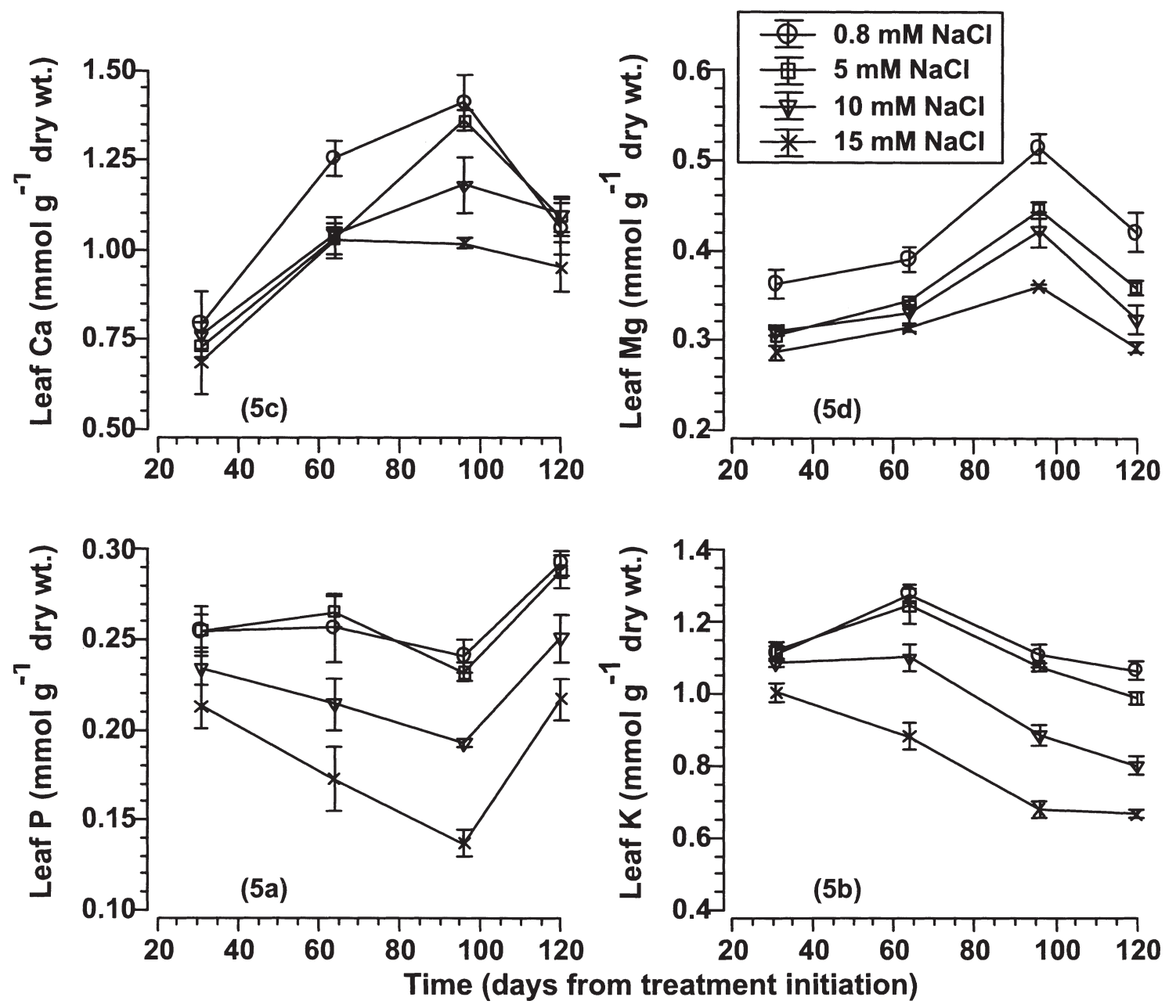

Fig. 5. Concentrations of $\mathrm{P}, \mathrm{K}, \mathrm{Ca}$ and $\mathrm{Mg}$ during $120 \mathrm{~d}$ of drainage solution recycling in the 5 th leaf from the apex of shoots of cucumber grown in a completely closed hydroponic system as influenced by the $\mathrm{NaCl}$ concentration in the irrigation water used to compensate for transpiration losses.

$\mathrm{mM} \mathrm{NaCl}$, respectively (Fig. 4b). Significant differences between the treatments were first observed $23 \mathrm{~d}$ after planting ( $18 \mathrm{~d}$ after recycling initiation), and were further enlarged on day 57 , but remained constant thereafter. It has been shown that a gradual exposure of plants to salinity is less detrimental than a rapid increase of the salt concentration, because in the former case the plants can adjust their osmotic status (El-Shourbagy and Ahmed, 1975; Slatyer, 1961). However, this may be of minor significance under conditions of long-term exposure to salinity, since the growth reduction observed in our experiment is comparable with that reported for cucumber by other investigators at similar $\mathrm{NaCl}$ levels in the rhizosphere (Drew et al., 1990; Sonneveld and de Kreij, 1999), which were not as gradually imposed as in the present study.

Cucumber is considered a salt sensitive plant species (Drew et al., 1990; Jones et al., 1989). The appreciable suppression of cucumber shoot growth at $\mathrm{NaCl}$ levels in the root environment up to 55 to $60 \mathrm{~mm}$ (Fig. 4) is in agreement with the above statement. According to Sonneveld (2000), cucumber is specifically sensitive to sodium chloride. Consideration of Figs. 1 and $4 \mathrm{a}$ reveals that the impact of salinity on water uptake and plant growth followed a similar pattern. This is reasonable, since plant transpiration and plant assimilation are physically connected by the concurrent diffusion of water vapor and carbon dioxide through the stomata. However, the suppression of shoot dry mass was stronger than that of water consumption. This indicates that growth may have been inhibited not only due to stomatal limitations. Drew et al. (1990) found that both chlorophyll content and net photosynthesis were adversely affected by salinity in cucumber, while water use efficiency decreased too. Based also on measurements of net assimilation as a function of the substomatal $\mathrm{CO}_{2}$ concentration, they concluded that the growth of cucumber was suppressed mainly due to impairment of the photosynthetic apparatus at chloroplast level.

The concentration of $\mathrm{P}$ in the leaf of cucumber was not influenced as the $\mathrm{Na}$ and $\mathrm{Cl}$ concentration increased to approximately $30 \mathrm{mM}$ in the external solution, but was suppressed as the levels of $\mathrm{Na}$ and $\mathrm{Cl}$ in the root zone were further raised to values above 40 mM (Fig. 5a). Diminished leaf P concentrations due to $\mathrm{NaCl}$ salinity have been found predominantly in experiments with soil grown crops, and were attributed to reduced activity of $P$ in soil solution (Grattan and Grieve, 1999). In contrast, in soilless grown crops the leaf $\mathrm{P}$ concentration is either not affected or increased by $\mathrm{NaCl}$ salinity (Grattan and Grieve, 1999; Kawasaki et al., 1983), presumably because $\mathrm{Cl}^{-}$and $\mathrm{H}_{2} \mathrm{PO}_{4}^{-}$are not competitive in terms of plant uptake (Champagnol, 1979). Cucumber seems to be one of the exceptions, since in the present experiment the leaf $\mathrm{P}$ level was markedly reduced when the $\mathrm{NaCl}$ concentration in the external solution was higher that $25 \mathrm{mM}(10$ and $15 \mathrm{mM} \mathrm{NaCl}$ in the irrigation water).

The translocation of $\mathrm{K}$ to the leaves of cucumber was not significantly reduced after gradual exposure of the plant to external concentrations up to $30 \mathrm{~mm} \mathrm{NaCl}$ but was markedly restricted at higher salinity levels (Fig. $5 b)$. Reduced $\mathrm{K}$ concentrations in cucumber leaf due to $\mathrm{NaCl}$-salinity have been reported also by Drew et al. (1990). Potassium is the most prominent inorganic solute contributing to the maintenance of turgor pressure in cell protoplast (Marschner, 1995). Hence, a restricted $\mathrm{K}$ availability may affect physiological procedures depending on turgor maintenance in tissues and cell compartments where a substitution of $\mathrm{K}$ by $\mathrm{Na}$ is not possible due to the high sodium toxicity (e.g., phloem loading).

The leafCa concentration was significantly diminished when the external $\mathrm{Na}$ and $\mathrm{Cl}$ levels were about 55 and $60 \mathrm{~mm}$, respectively (Fig. $5 \mathrm{c})$. However, in August the leaf Ca concentration was significantly restricted even with 
nearly $30 \mathrm{~mm} \mathrm{NaCl}$ in the root environment. Reduced Ca translocation to the leaf is a common response of many plants to salinity and seems to originate predominantly from the suppression of transpiration rates (Ho and Adams, 1994). The leaf Mg concentration of cucumber exhibited the highest sensitivity to $\mathrm{NaCl}$ salinity, since it was diminished on all sampling dates even with about $30 \mathrm{~mm} \mathrm{Na}$ and $\mathrm{Cl}$ in the root zone (Fig. 5d). Nevertheless, the decrease of the leaf $\mathrm{Mg}$ concentration was not proportional to the level of salinity as the latter was further increasing. Increased salinity is not always associated with decreases in leaf $\mathrm{Mg}$ (Grattan and Grieve, 1999). Hence, the appreciable suppression of leaf Mg even with salinity levels up to $30 \mathrm{~mm} \mathrm{NaCl}$, as well as those of $\mathrm{K}$ and $\mathrm{P}$, may indicate a specific inability of cucumber to maintain optimal nutrient levels under salt stress conditions. Nevertheless, the leaf $\mathrm{K}, \mathrm{Ca}$, and $\mathrm{Mg}$ concentrations measured in cucumber leaf in this study were within the corresponding ranges of adequacy (Marschner, 1995) even in the treatments resulting in high salinity levels in the rhizosphere. Hence, it is reasonable to conclude that the restricted translocation of $\mathrm{P}, \mathrm{K}, \mathrm{Ca}$, and $\mathrm{Mg}$ to leaf was a consequence and not a cause of the high salt sensitivity of cucumber.

\section{Conclusions}

Cucumber is susceptible to gradual accumulation of $\mathrm{Na}$ and $\mathrm{Cl}$ in completely closed hydroponic systems. Plant growth, water consumption, and uptake of $\mathrm{P}, \mathrm{K}$, and $\mathrm{Mg}$ are severely restricted as the $\mathrm{Na}$ and $\mathrm{Cl}$ concentrations in the root environment increase. The course of $\mathrm{Na}$ and $\mathrm{Cl}$ accumulation may be predicted as a function of cumulative water uptake and this may be used to create intelligent automation systems enabling a better management of fertigation effluents in closed hydroponic systems. However, the empirically determined parameters linking the Na to water and $\mathrm{Cl}$ to water uptake ratios with the $\mathrm{Na}$ and $\mathrm{Cl}$ concentrations in the root zone may alter to some extent as the latter rise above a threshold, as well as at different seasons of the year. Hence, to obtain a more accurate estimation of the $\mathrm{Na}$ and $\mathrm{Cl}$ concentrations in the rhizosphere as functions of the cumulative water uptake, further research is needed for each plant species. Such research should be aimed at establishing special relationships between root zone and uptake concentrations of $\mathrm{Na}$ and $\mathrm{Cl}$ for low and high $\mathrm{NaCl}$ concentrations in the irrigation water as well as for different seasons of the year.

\section{Literature cited}

Adams, P. 2002. Nutritional control in hydroponics, p. 211-261. In: D. Savvas and H.C. Passam (eds.). Hydroponic production of vegetables and ornamentals. Embryo Publ., Athens, Greece.

Baas, R. H.M.C. Nijssen, T.J.M. van der Berg, and M.G. Warmenhoven. 1995. Yield and quality of carnation (Dianthus caryophyllus L.) and gerbera (Gerbera jamesonii L.) in a closed nutrient system as affect by sodium chloride. Sci. Hort. 61:273-284.

Bar-Yosef, B., T. Markovich, and I. Levkovich. 1999. Pepper response to leachate recycling in a greenhouse in Israel. Acta Hort. 548:357-364.

Bar-Yosef, B, T. Markovich, I. Levkovich, and Y. Mor. 2000. Gypsophila paniculata response to leachate recycling in a greenhouse in Israel. Acta Hort. 554:193-203.

Butcher J.C. 1987. The numerical analysis of ordinary differential equations: Runge-Kutta and general linear methods. Wiley, London.

Carmassi, G., L. Incrocci, R. Maggini, F. Malorgio, F. Tognoni, and A. Pardossi. 2004. Modelling salinity build-up in recirculating nutrient solution culture. J. Plant Nutr. 28:431-445.

Champagnol, F. 1979. Relationships between phosphate nutrition of plants and salt toxicity. Phosphorus Agr. 76:35-43.

Drew, M.C., P.S. Hole, and G.A. Picchioni. 1990 Inhibition by $\mathrm{NaCl}$ of net $\mathrm{CO}_{2}$ fixation and yield of cucumber. J. Amer. Soc. Hort. Sci. 115:472-477.

Eaton,A.D, L.S. Clesceri, and A.E. Greenberg (eds.). 1995. Standard methods for the examination of water and wastewater. $19^{\text {th }}$ ed. Amer. Public Health Assn. Wash., D.C.

El-Shourbagy, M.N. and A.M. Ahmed. 1975. Responses of two varieties of tomato to abrupt and gradual short-period sodium chloride exposure. Plant Soil 42:255-271.

Flowers, T.J. 2004. Improving crop salt tolerance. J. Expt. Bot. 55:307-319.

Grattan, S.R and C.M. Grieve. 1999. Salinity-mineral nutrient relations in horticultural crops. Sci. Hort. 78:127-157.

Greenway, H. and R. Munns. 1980. Mechanisms of salt tolerance in nonhalophytes. Annu. Rev. Plant Physiol. 31:149-190.

Ho, L.C. and P. Adams. 1994. The physiological basis for high fruit yield and susceptibility to calcium deficiency in tomato and cucumber. $\mathrm{J}$. Hort. Sci. 69:367-376.

Hopmans, J.W. and K.L. Bristow. 2002. Current capabilities and future needs of root water and nutrient uptake modelling. Adv. Agron. 77:103-183.

Hsiao, T.C. 1993. Effects of drought and elevated $\mathrm{CO}_{2}$ on plant water use efficiency and productivity. In: M.B. Jackson and C.R. Black (eds.). Interacting stresses on plants in a changing climate. NATO ASI Series. vol. I 16. Springer Verlag, Berlin.

Jones, Jr., R.W., L.M. Pike, and L.F. Yourman. 1989. Salinity influences cucumber growth and yield.
J. Amer. Soc. Hort. Sci. 114:547-551.

Kawasaki, T., T. Akiba, and M. Moritsugu. 1983. Effects of high concentrations of sodium chloride and polyethylene glycol on the growth and ion absorption in plants. I. Water culture experiments in greenhouse. Plant Soil 75:75-85.

Klieber, A., W.C. Lin, P.A. Jolliffe, and J.W. Hall. 1993. Training systems affect canopy light exposure and shelf life of long english cucumber. J. Amer. Soc. Hort. Sci. 118:786-790.

Le Bot, J., S. Adamowicz, and P. Robin. 1998. Modeling plant nutrition of horticultural crops: a review. Sci. Hort. 74:47-82.

Marschner, H. 1995. Mineral nutrition of higher plants. 2nd ed. Academic Press, London.

Munns, R. 2002. Comparative physiology of salt and water stress. Plant Cell Environ. 25:239-250.

Raviv, M., A. Krasnovsky, S. Medina, and R. Reuveni. 1998. Assessment of various control strategies for recirculation of greenhouse effluents under semi-arid conditions. J. Hort. Sci. Biotechnol. 73:485-491.

Savvas, D. 2002a. Nutrient solution recycling, p. 299-343. In: D. Savvas and H.C. Passam (eds.). Hydroponic production of vegetables and ornamentals. Embryo Publ., Athens, Greece.

Savvas, D. 2002b. Automated replenishment of recycled greenhouse effluents with individual nutrients in hydroponics by means of two alternative models. Biosyst. Eng. 83:225-236.

Savvas, D. and F. Lenz. 1995. Nährstoffaufnahme von Aubergine (Solanum melongena L.) in Hydrokultur. Gartenbauwissenschaft 60:29-33.

Savvas, D., V.A. Pappa, G. Gizas, and A. Kotsiras. 2005. $\mathrm{NaCl}$ accumulation in a cucumber crop grown in a completely closed hydroponic system as influenced by $\mathrm{NaCl}$ concentration in irrigation water. Euro. J. Hort. Sci. (in press).

Silberbush, M. and J. Ben-Asher. 2001. Simulation study of nutrient uptake by plants from soilless cultures as affected by salinity buildup and transpiration. Plant Soil 233:59-69.

Slatyer, R.O. 1961. Effects of several osmotic substrates on water relations of tomato. Austr. J. Biol. Sci. 14:519-540.

Sonneveld, C. 2000. Effects of salinity on substrate grown vegetables and ornamentals in greenhouse horticulture. PhD diss. Univ. Wageningen, The Netherlands.

Sonneveld, C. 2002. Composition of nutrient solutions, p. 179-210. In: D. Savvas and H.C. Passam (eds.). Hydroponic production of vegetables and Ornamentals. Embryo Publ., Athens, Greece.

Sonneveld, C. and C. De Kreij. 1999. Response of cucumber (Cucumis sativus L.) to an unequal distribution of salts in the root environment. Plant Soil 209:47-56.

Sonneveld, C., R. Baas, H.M.C. Nijssen, and J. de Hoog. 1999. Salt tolerance of flower crops grown in soilless culture. J. Plant Nutr. 22:1033-1048.

Van Os, E.A. 1999. Closed soilless growing systems: A sustainable solution for Dutch greenhouse horticulture. Water Sci. Technol. 39:105-112. 